University of Nebraska - Lincoln

DigitalCommons@University of Nebraska - Lincoln

\title{
Calibration of remotely sensed, coarse resolution NDVI to CO2 fluxes in a sagebrush-steppe ecosystem
}

\author{
Bruce K. Wylie \\ USGS EROS, wylie@usgs.gov \\ Douglas A. Johnson \\ Utah State University \\ Emilio Laca \\ University of California - Davis, ealaca@ucdavis.edu \\ Nicanor Z. Saliendra \\ Utah State University \\ Tagir G. Gilmanov \\ South Dakota State University, tagir.gilmanov@sdstate.edu \\ See next page for additional authors
}

Follow this and additional works at: https://digitalcommons.unl.edu/usgsstaffpub

Part of the Geology Commons, Oceanography and Atmospheric Sciences and Meteorology Commons, Other Earth Sciences Commons, and the Other Environmental Sciences Commons

Wylie, Bruce K.; Johnson, Douglas A.; Laca, Emilio; Saliendra, Nicanor Z.; Gilmanov, Tagir G.; Reed, Bradley C.; Tieszen, Larry L.; and Worstell, Bruce B., "Calibration of remotely sensed, coarse resolution NDVI to CO2 fluxes in a sagebrush-steppe ecosystem" (2003). USGS Staff -- Published Research. 629.

https://digitalcommons.unl.edu/usgsstaffpub/629

This Article is brought to you for free and open access by the US Geological Survey at DigitalCommons@University of Nebraska - Lincoln. It has been accepted for inclusion in USGS Staff -- Published Research by an authorized administrator of DigitalCommons@University of Nebraska - Lincoln. 


\section{Authors}

Bruce K. Wylie, Douglas A. Johnson, Emilio Laca, Nicanor Z. Saliendra, Tagir G. Gilmanov, Bradley C. Reed, Larry L. Tieszen, and Bruce B. Worstell 


\title{
Calibration of remotely sensed, coarse resolution NDVI to $\mathrm{CO}_{2}$ fluxes in a sagebrush-steppe ecosystem
}

\author{
Bruce K. Wylie ${ }^{\mathrm{a}, *}$, Douglas A. Johnson ${ }^{\mathrm{b}}$, Emilio Laca ${ }^{\mathrm{c}}$, Nicanor Z. Saliendra ${ }^{\mathrm{b}}$, \\ Tagir G. Gilmanov ${ }^{\mathrm{d}}$, Bradley C. Reed ${ }^{\mathrm{a}}$, Larry L. Tieszen $^{\mathrm{e}}$, Bruce B. Worstell ${ }^{\mathrm{a}}$ \\ ${ }^{a}$ USGS EROS Data Center, Raytheon Systems Company, Sioux Falls, SD 57198-0001, USA \\ ${ }^{\mathrm{b}}$ U.S. Department of Agriculture, Agricultural Research Service, Forage and Range Research Laboratory, Utah State University, Logan, UT, USA \\ ${ }^{\mathrm{c}}$ Department of Agronomy and Range Science, University of California, Davis, CA, USA \\ ${ }^{\mathrm{d}}$ Department of Biology and Microbiology, South Dakota State University, Brookings, SD, USA \\ ${ }^{\mathrm{e}}$ U.S. Geological Survey, EROS Data Center, Sioux Falls, SD, USA
}

Received 10 May 2002; received in revised form 19 November 2002; accepted 23 November 2002

\begin{abstract}
The net ecosystem exchange (NEE) of carbon flux can be partitioned into gross primary productivity (GPP) and respiration $(R)$. The contribution of remote sensing and modeling holds the potential to predict these components and map them spatially and temporally. This has obvious utility to quantify carbon sink and source relationships and to identify improved land management strategies for optimizing carbon sequestration. The objective of our study was to evaluate prediction of 14-day average daytime $\mathrm{CO}_{2}$ fluxes $\left(F_{\text {day }}\right)$ and nighttime $\mathrm{CO}_{2}$ fluxes $\left(R_{\mathrm{n}}\right)$ using remote sensing and other data. $F_{\text {day }}$ and $R_{\mathrm{n}}$ were measured with a Bowen ratio-energy balance (BREB) technique in a sagebrush (Artemisia spp.)-steppe ecosystem in northeast Idaho, USA, during 1996-1999. Micrometeorological variables aggregated across 14-day periods and time-integrated Advanced Very High Resolution Radiometer (AVHRR) Normalized Difference Vegetation Index (iNDVI) were determined during four growing seasons $(1996-1999)$ and used to predict $F_{\text {day }}$ and $R_{\mathrm{n}}$. We found that iNDVI was a strong predictor of $F_{\text {day }}$ $\left(R^{2}=0.79, n=66, P<0.0001\right)$. Inclusion of evapotranspiration in the predictive equation led to improved predictions of $F_{\text {day }}\left(R^{2}=0.82\right.$, $n=66, P<0.0001)$. Crossvalidation indicated that regression tree predictions of $F_{\text {day }}$ were prone to overfitting and that linear regression models were more robust. Multiple regression and regression tree models predicted $R_{\mathrm{n}}$ quite well $\left(R^{2}=0.75-0.77, n=66\right)$ with the regression tree model being slightly more robust in crossvalidation. Temporal mapping of $F_{\text {day }}$ and $R_{\mathrm{n}}$ is possible with these techniques and would allow the assessment of NEE in sagebrush-steppe ecosystems. Simulations of periodic $F_{\text {day }}$ measurements, as might be provided by a mobile flux tower, indicated that such measurements could be used in combination with iNDVI to accurately predict $F_{\text {day. }}$. These periodic measurements could maximize the utility of expensive flux towers for evaluating various carbon management strategies, carbon certification, and validation and calibration of carbon flux models.
\end{abstract}

(C) 2003 Elsevier Science Inc. All rights reserved.

Keywords: Carbon dioxide; Primary production; Respiration; NDVI; Artemisia

\section{Introduction}

Increasing atmospheric $\mathrm{CO}_{2}$ concentrations and their potential impacts on global change are the subject of widespread studies, political debates, and international discussions. Although the status of carbon stocks in both biomass and soil organic matter has been estimated for various ecosystems (Fallon et al., 1998; Gilmanov \& Oechel,

\footnotetext{
* Corresponding author. Tel.: +1-605-594-6078; fax: +1-605-5946529.

E-mail address: wylie@usgs.gov (B.K. Wylie).
}

1995; Hunt, Lavigne, \& Franklin, 1999), $\mathrm{CO}_{2}$ fluxes from these ecosystems and their driving forces are not well understood either locally or globally (Cihlar et al., 2002). Discussions to reduce or curtail the rate of atmospheric $\mathrm{CO}_{2}$ increases (Fallon et al., 1998; Pfaff et al., 2000) have suggested that terrestrial (biological) sinks might be used to partially offset industrial $\mathrm{CO}_{2}$ sources in a global market system for carbon sequestration. The possible effectiveness of these terrestrial sinks and the quantitative estimates of their "sink strengths" have relied mainly on measurements of changes in carbon stocks.

Recent developments in measurement techniques for assessing $\mathrm{CO}_{2}$ fluxes provide tools for quantifying the net 
ecosystem exchange (NEE) of $\mathrm{CO}_{2}$ on a continuous, daily basis at point sources. The potential value of these near realtime measurements to quantify $\mathrm{CO}_{2}$ flux rates, their driving forces, and annual fluxes has resulted in integrated research efforts across a variety of land-cover and land-use types as seen in the Ameriflux Network (Desjardins, Hart, Macpherson, Schuepp, \& Verma, 1992), Euroflux Network (Aubinet et al., 2000), and a network of rangeland ecosystem sites in the western USA established by the U.S. Department of Agriculture's Agricultural Research Service (USDA-ARS) (Svejcar, Mayeux, \& Angell, 1997). Sole reliance on field point samples can lead to biased regional estimates of $\mathrm{CO}_{2}$ fluxes or production (Biondini, Lauenroth, \& Sala, 1991; Rahman, Gamon, Fuentes, Roberts, \& Prentiss, 2001). The extrapolation of site-specific data across broad spatial scales requires a modeling approach to extend the site-specific algorithms to similar land-cover types (Reich et al., 1999; Running et al., 1999; Vourlitis et al., 2000). Establishing these relationships could be the basis for mapping $\mathrm{CO}_{2}$ fluxes across landscapes and regions, and could assist in evaluating various land-use management alternatives to optimize carbon sequestration, including sink development (Bounoua et al., 2000; Fallon et al., 1998; Gilmanov \& Oechel, 1995; Kelly, Hunt, Reiners, Smith, \& Welker, 2002; Prince \& Steininger, 1999; Tucker, Fung, Keeling, \& Gammon, 1986; Williams, Eugster, Rastetter, McFadden, \& Chapin, 2000).

Quantification of carbon fluxes, either in natural systems or under different management scenarios, can be accomplished across extended time periods by assessment of carbon stocks (Bliss, Waltman, \& Petersen, 1995; Fallon et al., 1998; Gilmanov \& Oechel, 1995) or across annual time periods by measurement of $\mathrm{CO}_{2}$ fluxes with micrometeorological techniques such as eddy covariance and Bowen ratio-energy balance (BREB) methods (Frank \& Dugas, 2001; Rosenberg, 1983; Sims \& Bradford, 2001). Micrometeorological approaches for estimating $\mathrm{CO}_{2}$ fluxes, including the eddy covariance technique and the BREB method, provide a means to estimate $\mathrm{CO}_{2}$ flux at specific sites. A detailed description of micrometeorological and the theories behind them can be found in Moncrieff, Valentini, Greco, Seufert, and Ciccioli (1997). The eddy covariance technique is a direct method of measuring fluxes and measures vertical wind speed, wind direction, and $\mathrm{CO}_{2}$ concentration of air moving past a sampling point. The eddy covariance method is advantageous because it is a direct method of measurement; however, this method requires electronically sophisticated equipment. Additionally, recent studies indicate that energy fluxes such as net radiation (NR) and soil heat flux should be determined concurrently with eddy covariance measurements to correct fluxes for lack of energy balance closure (Twine et al., 2000).

Indirect methods of measuring $\mathrm{CO}_{2}$ fluxes include the aerodynamic and BREB techniques, which quantify the rate of diffusion down a concentration gradient. The aerodynamic method has the advantage that it uses simple instru- mentation, but the technique has limitations within canopies or in canopies with small gradients (Raupach, 1988). The BREB technique is based on the law of energy conservation and has been used extensively to determine the components of energy balance and evapotranspiration as well as $\mathrm{CO}_{2}$ fluxes above various crop canopies (e.g., Baldocchi, Verma, \& Rosenberg, 1981; Dugas et al., 1991; Dugas, Heuer, \& Mayeux, 1999; Frank \& Dugas, 2001; Kim, Verma, \& Rosenberg, 1989; Sims \& Bradford, 2001; Verma \& Rosenberg, 1975). The BREB method is advantageous because it uses simpler sensors than eddy covariance techniques, but is difficult to apply during periods when net radiation and gradients in temperature are small (e.g., at sunrise and sunset). Nevertheless, these micrometeorological techniques have been well validated during the past 30 years (Moncrieff et al., 1997). Although eddy correlation and BREB techniques have shown acceptable agreement in semiarid environments (Unland, Houser, Shuttleworth, \& Yang, 1996), reliable surface energy fluxes were easier to determine with the BREB method, but the eddy covariance method provided greater accuracy for short time periods.

Modeled estimates of carbon fluxes or other biophysical parameters can be mapped over regions using either physical models (Kohlmaier et al., 1997; Pan et al., 1998; Randall, Dazlich, Zhang, \& Denning, 1996) or empirical statistical models (Paruelo, Epstein, Lauenroth, \& Burke, 1997; Wylie, Harrington, Prince, \& Denda, 1991). Statistical models can reveal new useful relationships (De'ath \& Fabricius, 2000; Prince \& Steininger, 1999) and are simple, easily constructed, and work with relative or surrogate input layers. Statistical techniques represent the population from which the training samples were taken, but may be erroneous when extrapolated beyond the range (data values, time, and space) of the training data (Asner \& Wessman, 1997; Hall, Knapp, \& Huemmrich, 1997). Functional models are often complex, include numerous assumptions, and require accurate data inputs calibrated to standard physical units (Bonan, 1995; Gilmanov, Parton, \& Ojima, 1997; Hall et al., 1997; Liu et al., 2002). Functional models typically perform better than statistical models on unique or new circumstances, but intensive input requirements often are a major constraint. Functional models allow assessment of long-term trends and can be used to evaluate various input scenarios. Innovative combinations of remote sensing and functional models have proven useful (Asner, Bateson, Privette, El Saleous, \& Wessman, 1998; Asner \& Wessman, 1997; Field, Randerson, \& Malmstrom, 1995; Liu et al., 2002; Pfaff et al., 2000; Potter et al., 1993; Reich, Turner, \& Bolstad, 1999; Sellers et al., 1997; Williams et al., 2000). Regional estimation and mapping of $\mathrm{CO}_{2}$ flux should utilize simple algorithms (Reich et al., 1999) with remote sensing input (Field, Gamon, \& Penuelas, 1994; Hall, Townsend, \& Engman, 1995; Kelly et al., 2002; Reich et al., 1999; Vourlitis et al., 2000).

Advanced Very High Resolution Radiometer (AVHRR) Normalized Difference Vegetation Index (NDVI) data are 
well suited for studies of ecosystem dynamics from regional to global scales. NDVI has successfully tracked biophysical variables (Bartlett, Whitting, \& Hartman, 1990; Chen \& Brutsaert, 1998; Purevdorj, Tateishi, Ishiyama, \& Honda, 1998; Seen, Mougin, Rambal, Gaston, \& Hiernaux, 1995; Wylie et al., 1991; Wylie, Meyer, Tieszen, \& Mannel, 2002), production (Gilabert, Masellin, Conese, \& Bindi, 1995; Paruelo et al., 1997), and $\mathrm{CO}_{2}$ fluxes (Bartlett et al., 1990; Cihlar, Caromori, Schuepp, Desjardins, \& MacPherson, 1992; Mack, Desjardins, MacPherson, \& Schuepp, 1990; Oechel et al., 2000) in grasslands and shrublands. However, the decoupling of $\mathrm{CO}_{2}$ flux and the vegetation indices were observed in the boreal forest and attributed to very low radiation use efficiency (RUE) of coniferous evergreens, incomplete accounting of below canopy production, and canopy clumpiness (Gower, Kucharik, \& Norman, 1999; Loechel et al., 1997). The integration of remotely sensed and $\mathrm{CO}_{2}$ flux data could provide a more efficient and accurate modeling and prediction of carbon fluxes at the landscape and regional levels.

A widely spaced network of eddy covariance or BREB flux towers would be required to insure model robustness (Cihlar et al., 2002; Cohen \& Justice, 1999; Reich et al., 1999; Running et al., 1999) and to minimize spatial autocorrelation effects for regional mapping with statistical models using remote sensing and GIS (Cairns, 2001). However, networks of permanently located flux towers are expensive to operate and maintain. Mobile flux towers in combination with remote sensing techniques and meteorological data may help maximize the utility of flux towers. Certification of carbon sequestration activities (Gustavsson et al., 2000) could be monitored using mobile flux towers combined with remote sensing and models to predict fluxes when the tower is offsite. This approach could be used to both increase $\mathrm{CO}_{2}$ flux data for model development and improve the spatial representation of those data. The objective of our study was to evaluate if remotely sensed NDVI can be used to predict $\mathrm{CO}_{2}$ fluxes in a sagebrush-steppe ecosystem in central Idaho, USA, and to determine if less frequent measurements could accurately predict continuously measured $\mathrm{CO}_{2}$ fluxes.

\section{Theory}

The instantaneous rate of $\mathrm{CO}_{2}$ flux or NEE can be described in two alternative ways. NEE can be described as the difference between gross primary productivity (GPP) and respiration $(R)$ :

$\mathrm{NEE}=\mathrm{GPP}-R$

which facilitates a better understanding of carbon balances (Choudhury, 2000, 2001). In terms of the dynamics of the total ecosystem carbon stock $\left(C_{\mathrm{t}}\right)$, NEE may be described as:

$\mathrm{NEE}=\mathrm{d} C / \mathrm{d} t+E$

where $C$ is carbon density in an ecosystem, $t$ is time, and $E$ denotes the rate of soil erosion, which can be significant such as when grassland is converted to shrubland (Parizek, Rostagno, \& Sottini, 2002). The combination of flux tower measurements (Eq. (1)) with the dynamics of carbon stock assessment (Eq. (2)) opens the possibility of being able to evaluate rates of soil erosion even in those cases when direct experimental measurements of $E$ are difficult.

The conceptual basis for modeling GPP is often Monteith's equation or the radiation use efficiency (RUE) model (Field et al., 1995; Kelly et al., 2002; Monteith, 1977; Paruelo et al., 1997; Potter et al., 1993; Rahman et al., 2001). The RUE model defines the components of GPP for a given time period as total absorbed photosynthetically active radiation (APAR) and the RUE coefficient $(\varepsilon)$ :

$\mathrm{GPP}=\varepsilon \mathrm{APAR}$

APAR can be derived from photosynthetically active radiation (PAR) reaching the Earth's surface (Lopez, Rubio, Martinez, \& Batlles, 2001) and the fraction of PAR absorbed by plants (fPAR):

$\mathrm{APAR}=\mathrm{PAR} \times \mathrm{PPAR}$

Relationships between remotely sensed data and PPAR have been developed (Bartlett et al., 1990; Chen, 1996; Gamon et al., 1995; Knyazikhin et al., 1999; Tieszen, Reed, Bliss, Wylie, \& DeJong, 1997; Wylie et al., 2002) and may facilitate regional mapping of NEE and rangeland production (Reeves, Winslow, \& Running, 2001; Wylie et al., 1991). The RUE framework may be useful in estimating net primary production (NPP) (Turner et al., 2002) and $\mathrm{CO}_{2}$ fluxes, but must be carefully quantified (Gamon et al., 1995) and may introduce regional biases (Choudhury, 2001). Drought (Bartlett et al., 1990; Hanan, Prince, \& Begue, 1995; Jamieson, Martin, Francis, \& Wilson, 1995), photosynthetic pathway type $\left(\mathrm{C}_{3}\right.$ versus $\mathrm{C}_{4}$; Hanan, Prince, \& Begue, 1997), variations in PAR (Rahman et al., 2001), and land cover/vegetation structure (Asner et al., 1998; Gower et al., 1999; Mack et al., 1990) affect the value of $\varepsilon$.

The linear relationship between NPP or NEE and timeintegrated NDVI (iNDVI) (Seen et al., 1995) was principally driven by their relationship to GPP. Mapping of GPP or surrogates, such as daytime fluxes $\left(F_{\text {day }}\right)$, can be estimated with remote sensing as one of the inputs (Reeves et al., 2001; Vourlitis et al., 2000). Mapping of $\mathrm{CO}_{2}$ sources and sinks and their strengths (NEE) requires that $R$ must also be mapped because GPP and $R$ do not necessarily covary (Anthoni, Law, \& Unsowrth, 1999; Law, Williams, Anthoni, Baldocchi, \& Unsworth, 2000). Because the functional relationships are different for GPP and $R$, Choudhury 
(2001) estimated daytime flux ( $\left.F_{\text {day }}\right)$ rather than NEE to minimize the confounding effects of nighttime fluxes $\left(R_{\mathrm{n}}\right)$, and Vourlitis et al. (2000) separately mapped GPP and total $R$. Respiration can be more relevant than GPP in the determination of $\mathrm{CO}_{2}$ source and sink strengths (Gilmanov, Johnson, \& Saliendra, 2003; Valentini et al., 2000).

Although remotely sensed vegetation indices are more closely correlated with GPP, they can help estimate $R$ components associated with autotrophic maintenance and growth $R$, which are related to live canopy biomass ( $\mathrm{Li}$ et al., 2002) or GPP. The primary mechanism for predicting and mapping $R$ has been through temperature (Oechel et al., 2000; Potter et al., 1993; Williams et al., 2000), while others have questioned this approach (Glardina \& Ryan, 2000). Soil water content or its surrogates also have been shown to be an important variable for predicting $R$ (Mielnick \& Dugas, 2000; Raich, Potter, \& Bhagawati, 2002; Tufekcioglu, Raich, Isenhart, \& Schultz, 2001; Valentini, Gamon, \& Field, 1995; Vourlitis et al., 2000), but soil moisture was not always important (Bajracharya, Lal, \& Kimbal, 2000). Wind speed also can affect soil $\mathrm{CO}_{2}$ fluxes associated with $R$ (Massman, Sommerfeld, Mosier, \& Zeller, 1997; Rahman et al., 2001; Takle et al., 2000). Others have used $R_{\mathrm{n}}$, available from flux towers, to estimate daytime $R$ (Rahman et al., 2001; Williams et al., 2000). Hyperbolic light-curve equations can derive GPP and $R$ estimates from flux tower data (Gilmanov et al., in press; Vourlitis et al., 2000), where $R$ would include both nighttime and daytime $R$.

\section{Methods}

\subsection{Site description}

The field site was at the U.S. Sheep Experiment Station $\left(44^{\circ} 16^{\prime} \mathrm{N}, 112^{\circ} 08^{\prime} \mathrm{W}\right)$, which is located $10 \mathrm{~km}$ north of Dubois on the Upper Snake River Plain of northeast Idaho, USA. The site is situated in the northeastern portion of the sagebrush-steppe ecosystem (West, 1983) at an elevation of about $1700 \mathrm{~m}$. The dominant shrub, grass, and forb on the study site were three-tipped sagebrush (Artemisia tripartita Rydb.), bluebunch wheatgrass [Pseudoroegneria spicata (Pursh) A Löve], and arrowleaf balsamroot [Balsamorhiza saggitata (Pursh) Nutt.], respectively. Other important species include green rabbitbrush [Chrysothamnus viscidiflorus (Hook.) Nutt.], big sagebrush (Atremisia tridentata Nutt.), needle-and-thread grass (Stipa comata Trin. and Rupr.), and yarrow (Achillea millefolium L.).

Climate at the site is semiarid with cold winters and warm summers. Mean annual precipitation for the area during a 64-year period was $325 \mathrm{~mm}$, which included 70 $\mathrm{cm}$ of snow; the area has a mean annual temperature of $6{ }^{\circ} \mathrm{C}$ (NOAA, 1993). Temperatures range from $38{ }^{\circ} \mathrm{C}$ in summer to $-34{ }^{\circ} \mathrm{C}$ in winter with a normal frost-free period of $70-$ 90 days (Blaisdell, 1958). Soils at the site are loamy and derived from wind-blown loess, residue, or alluvium (Natural Resource Conservation Service [NRCS], 1995). Soil characteristics are variable across the landscape because of the varying thickness of parent material overlying the basalt bedrock and are composed of three mollisols on slopes ranging from $0 \%$ to $12 \%$. With increasing depth and degree of development, soils are classified as Typic Calcixerols (Anatolian series), Pachic Haploxerolls (Maremma series), and Pachic Argixerols (Akbash series).

\subsection{Bowen ratio measurements}

A relatively undisturbed area $(400 \times 400 \mathrm{~m})$ surrounded by similar vegetation and soils was fenced in 1995 to exclude grazing, and a BREB system was installed near the center of the enclosure to obtain continuous measurements of $\mathrm{CO}_{2}$ fluxes and associated micrometeorological characteristics. The theory and operation of the BREB system (Model 023/ $\mathrm{CO}_{2}$ Bowen Ratio; Campbell Scientific) are described in detail by Dugas (1993) and Dugas et al. (1999). Briefly, $\mathrm{CO}_{2}$ and water vapor concentrations were measured with an infrared gas analyzer (IRGA, ${ }^{1}$ Model LI6262; Li-Cor). Air samples from two heights ( 0.8 and $1.8 \mathrm{~m}$ above the soil surface) were drawn and routed to the IRGA, which measured the $\mathrm{CO}_{2}$ and water vapor concentration gradients between the two heights. Air temperature gradients at the two heights were simultaneously measured with fine-wire, chromel-constantan thermocouples. The $\mathrm{CO}_{2}$, water vapor, and temperature gradients were measured every second, and the average gradients were calculated and stored every $20 \mathrm{~min}$ with a data logger and storage module (Models 21X and SM192; Campbell Scientific). Fluxes of $\mathrm{CO}_{2}$, water vapor, and energy were calculated using 20-min averages. The eddy diffusivity, which was assumed equal for heat, water vapor, and $\mathrm{CO}_{2}$, was calculated from sensible heat flux and temperature gradients. The $\mathrm{CO}_{2}$ flux was calculated as the product of the eddy diffusivity and $\mathrm{CO}_{2}$ gradient and corrected for vapor density gradients at the two heights (Webb, Pearman, \& Leuning, 1980). The $\mathrm{CO}_{2}$ fluxes estimated by the BREB technique were shown to be similar to those measured by a closed chamber technique at two sagebrush-steppe sites in the western USA (Angell, Svejcar, Bates, Saliendra, \& Johnson, 2001). Various techniques have been used to fill in data gaps that occur in flux tower measurements (Falge et al., 2001). Day-specific solutions of nonlinear light-curve equations derived from the 20-min flux data were used in this study to fill data gaps (Gilmanov et al., in press).

During the 1996-1999 growing seasons, $\mathrm{CO}_{2}$ flux measurements were summarized as net daytime fluxes $\left(F_{\text {day }}\right), R_{\mathrm{n}}$, and net 24 -h fluxes $\left(F_{\text {net }}\right)$. The $\mathrm{CO}_{2}$ fluxes were also averaged into time intervals that coincided with the

\footnotetext{
1 Any use of trade, product, or firm name is for description purposes only and does not imply endorsement by the U.S. Government.
} 
NDVI biweekly composite periods and integrated across each of these periods. In this study, we used $F_{\text {day }}$ as an approximation of GPP, similar to Choudhury (2001), because $F_{\text {day }}$ was routinely obtained with the BREB system and $F_{\text {day }}$ minimized the confounding effects of $R_{\mathrm{n}}$, which was estimated separately.

\subsection{Satellite data}

NDVI data are affected by cloud contamination and atmospheric attenuation, which usually reduce the NDVI value (Los, Justice, \& Tucker, 1994). One method of reducing these effects is maximum value compositing (MVC); we used a compositing period of 14 days in our study. A weighted least squares linear regression approach to temporal NDVI smoothing was employed to reduce signal contamination (Swets, Reed, Rowland, \& Marko, 1999). We extracted NDVI values for the growing seasons of 1996-1999. To define the start and end of the growing season, we identified a well-defined trend change in NDVI values using a backward-or forward-looking, moving-average technique (Reed et al., 1994). The duration of the growing season was defined as the difference between the start and end of season. Values of NDVI associated with dormant vegetation or soil were used as a baseline to detect changes that indicated the onset of greenness and the end of the growing season. Linear temporal interpolation was used to estimate daily smoothed NDVI, and the respective baseline NDVI was subtracted. This was then summed for the growing season and each 2-week MVC period. The $\mathrm{CO}_{2}$ fluxes were compared to the time-integrated, smoothed NDVI values (iNDVI) for 2-week periods during the growing season, while iNDVI integrated across the growing season was used for annual comparisons.

\subsection{Statistical analysis}

Linear regression analysis was used to establish relationships between predictor variables and $F_{\text {day }}$ and $R_{\mathrm{n}}$ from the BREB flux tower using the independent variables listed in Table 1. Regression residual plots were visually inspected to assess assumptions of linearity and homogeneity of variance. The robustness of the models across years was tested using interaction and indicator variables with 1998 considered as the standard. The extra sums of squares principal were used to test whether combined year effects of both slope and intercept were significant beyond the sums of squares accounted for by a simple model (Neter, Wasserman, \& Kutner, 1983; Wylie, 1991). These multiple dependent tests warranted a conservative level of testing $(P<0.01)$ for year effects.

We were interested in determining if $F_{\text {day }}$ and $R_{\mathrm{n}}$ prediction could be improved with the additional meteorological and site variables listed in Table 1 and the subsequent application of regression tree techniques. Although not all of these variables would be easily available as spatial data sets
Table 1

Possible independent variables used to predict daytime $\left(F_{\text {day }}\right)$ and nighttime $\mathrm{CO}_{2}$ flux $\left(R_{\mathrm{n}}\right)$

\begin{tabular}{llll}
\hline Variables & Regression & $\begin{array}{l}\text { Regression } \\
\text { tree }\end{array}$ & Description \\
\hline iNDVI & $\mathrm{X}$ & $\mathrm{X}$ & $\begin{array}{l}\text { Time-integrated Normalized } \\
\text { Difference Vegetation Index } \\
\text { Photosynthetically active } \\
\text { radiation }\end{array}$ \\
PAR & $\mathrm{X}$ & $\mathrm{X}$ & Evapotranspiration \\
ET & $\mathrm{X}$ & $\mathrm{X}$ & Air temperature \\
TAIR & $\mathrm{X}$ & $\mathrm{X}$ & Precipitation \\
PPT & $\mathrm{X}$ & $\mathrm{X}$ & Vapor pressure deficit \\
VPD & $\mathrm{X}$ & $\mathrm{X}$ & Wind speed \\
WINDS & $\mathrm{X}$ & $\mathrm{X}$ & Relative humidity \\
RH & $\mathrm{X}$ & $\mathrm{X}$ & Net radiation \\
NR & & $\mathrm{X}$ & Soil temperature at $4 \mathrm{~cm}$ \\
TSOIL & & $\mathrm{X}$ & Volumetric soil water content \\
SOILW & & $\mathrm{X}$ & \\
\hline
\end{tabular}

across the landscape, they were quantified at the BREB tower in our study. Regression tree techniques are used to develop relationships and predictions that take nonlinearity into consideration, account for high-order interactions, and effectively use thematic or categorical data (De'ath \& Fabricius, 2000). These techniques hierarchically split the data and then allowed development of predictive linear equations for each of the various data subsets. Regression trees are useful for both stratification (Joel, Schimel, Friedl, Davis, \& Dubayah, 1994; Prince \& Steininger, 1999) and prediction (De'ath \& Fabricius, 2000). Three successive regression trees were produced with each successive regression tree attempting to correct prediction errors in the previous regression tree. ${ }^{2}$ The regression tree software quantified the number of training observations in each stratum in the regression tree models. The independent regression variables utilized in each stratum or "leaf node" were ordered by decreasing relevance. A program, which quantified the relative frequency of use of a variable in stratification as well as the cumulative relevance rank of all the independent variables for all the regressions, was written. This information was used to summarize multiple and sometimes complex series of successive regression trees.

To test the possibility of using periodic $F_{\text {day }}$ data (as might be provided by a mobile flux tower) compared to continuous flux data, we divided our flux data into three subsets (jack-knifing). Each subset simulated a revisit cycle from a mobile flux tower during every third biweekly composite period. Each of the three subsets had different sequential starting biweekly composite periods. Two biweekly composite periods for each subset were withheld from the analysis and used as independent tests for each sequence subset. As a result, regressions and regression trees assessing mobile flux towers were trained on a third of the data and tested on two-thirds of the data and repeated three times.

\footnotetext{
${ }^{2}$ See Committee models (www.rulequest.com/cubist-unix.html).
} 


\section{Results and discussion}

Values of $F_{\text {net }}, F_{\text {day }}$, iNDVI, and precipitation (PPT) were summed across NDVI composite periods 9-22 for 19961999. $F_{\text {net }}$ and $F_{\text {day }}$ were positive for all four growing seasons and increased steadily from 1996 to 1999, although iNDVI and PPT were lower in 1999 than 1998 (Fig. 1). Values of $F_{\text {net }}$ varied widely during the growing seasons of 1996-1999. $R_{\mathrm{n}}$, which is the difference between $F_{\text {day }}$ and $F_{\text {net, }}$ was reduced in 1999 and resulted in a slightly higher $F_{\text {net }}$ in 1999 than in 1998. This occurred despite higher PPT and iNDVI values in 1998. The weather characteristics and $\mathrm{CO}_{2}$ fluxes during the various growing seasons varied greatly during the study, suggesting that the derived models would likely be robust across a wide range of climatic, NDVI, and other input characteristics.

\subsection{Daytime $\mathrm{CO}_{2}$ flux $\left(F_{\text {day }}\right)$}

Linear relationships between MVC iNDVI and $F_{\text {day }}$ were strong ( $R^{2}$ from 0.79 to 0.92 ) for all years (Fig. 2). MVC periods with low or high precipitation were not associated with underestimation or overestimation of $F_{\text {day }}$ from iNDVI. NDVI has been proposed as a surrogate for potential photosynthesis (Yoder \& Waring, 1994). Decoupling of potential and actual photosynthesis is typically driven by drought stress or respiration (Gamon et al., 1995; Gower et al., 1999; Law et al., 2000), but this was not readily apparent in our data, despite the wide range in growing season NEE. This may have been attributable to our use of a 14-day MVC period. Estimation of $\mathrm{CO}_{2}$ fluxes from remotely sensed data may be more problematic for shorter MVC time periods or single days. Based on $R^{2}$ and the regression standard error, the strongest relationship between iNDVI and $F_{\text {day }}$ occurred in 1996, while the weakest occurred in 1998 (Fig. 2).
To assess the ability of iNDVI to predict the seasonal progression of $F_{\text {day, }}$ linear regression analyses were conducted using all years and all biweekly composites with the independent variables presented in Table 1. iNDVI was a strong predictor of $F_{\text {day }}$ (Table 2). In the analysis, $C(p)$ criteria (Freund \& Littell, 1995) from all possible combinations of independent variables identified iNDVI and ET as the optimal independent variables; however, iNDVI combined with PAR was also a strong predictor of $F_{\text {day }}$ $\left(R^{2}=0.81\right)$. Several methods for estimating spatial distributions of ET, precipitation, and temperature from remotely sensed and ancillary data have been used (Bristow \& Campbell, 1984; Caselles, 1993; Choudhury \& DiGirolamo, 1998; Kimball, Running, \& Nemani, 1997; Thornton \& Running, 1999; Xie \& Arkin, 1997) and allow spatial mapping of these variables. The simple iNDVI regression model was robust across years, but the multiple regression model had significantly different relationships in 1999. Accounting for significant year effects for 1999 with indicator and interaction terms resulted in unique slope and intercept coefficients (Neter et al., 1983) for 1999 and increased the $R^{2}$ value to 0.88 with no significant temporal autocorrelation. The temporal dynamics of iNDVI, ET, PPT, and $F_{\text {day }}$ in 1999 (Fig. 3) indicated that early season PPT, or maybe snow melt, may have contributed to deep soil water storage, which the deep-rooted sagebrush and other shrubs probably used later in the hot, dry summer to continue photosynthesis into composite period 13 . This peak in $F_{\text {day }}$ was not tracked well by iNDVI, indicating either possible increases in RUE or incomplete removal of subpixel cloud effects by compositing and temporal smoothing procedures.

The inclusion of ET in the multiple regression model may somehow correct for variable RUE and $R$. Bartlett et al. (1990) found that the relationship between NEE and NDVI improved when ambient air temperature was included in the

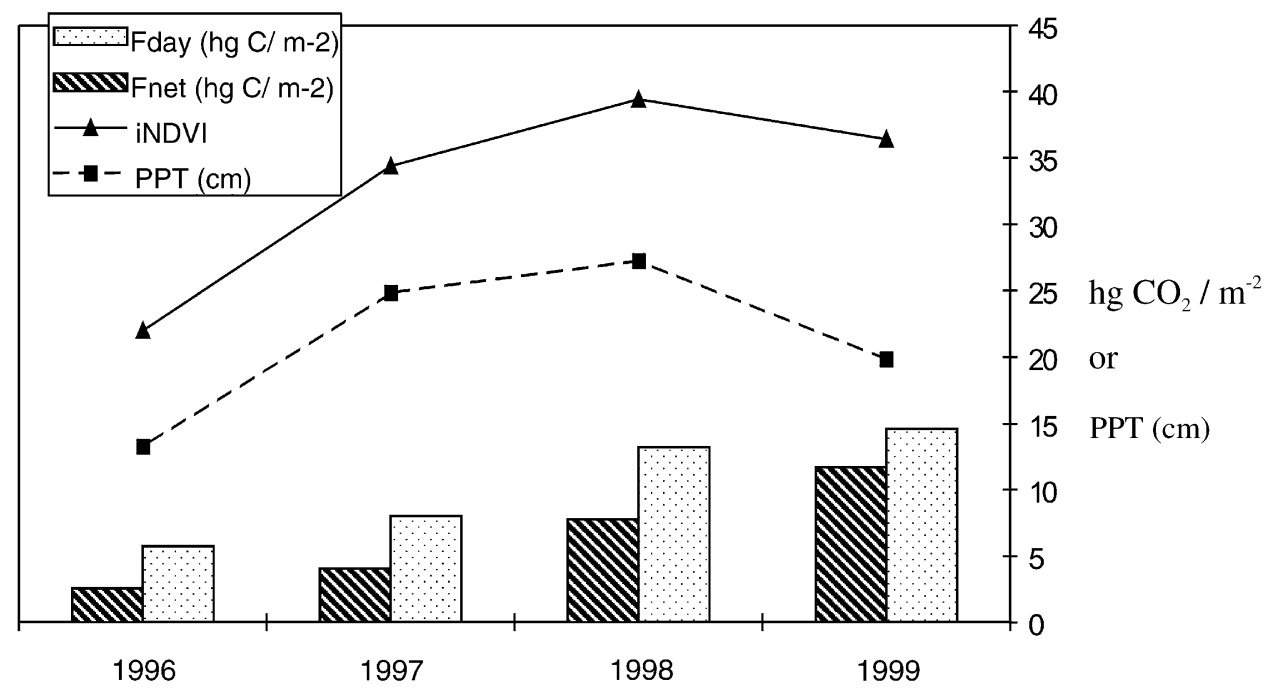

Fig. 1. Cumulative net $\left(F_{\text {net }}\right)$ and daytime ( $\left.F_{\text {day }}\right) \mathrm{CO}_{2}$ fluxes, integrated NDVI (iNDVI), and precipitation (PPT) across the growing season (March-July) for the 4 years of our study. 

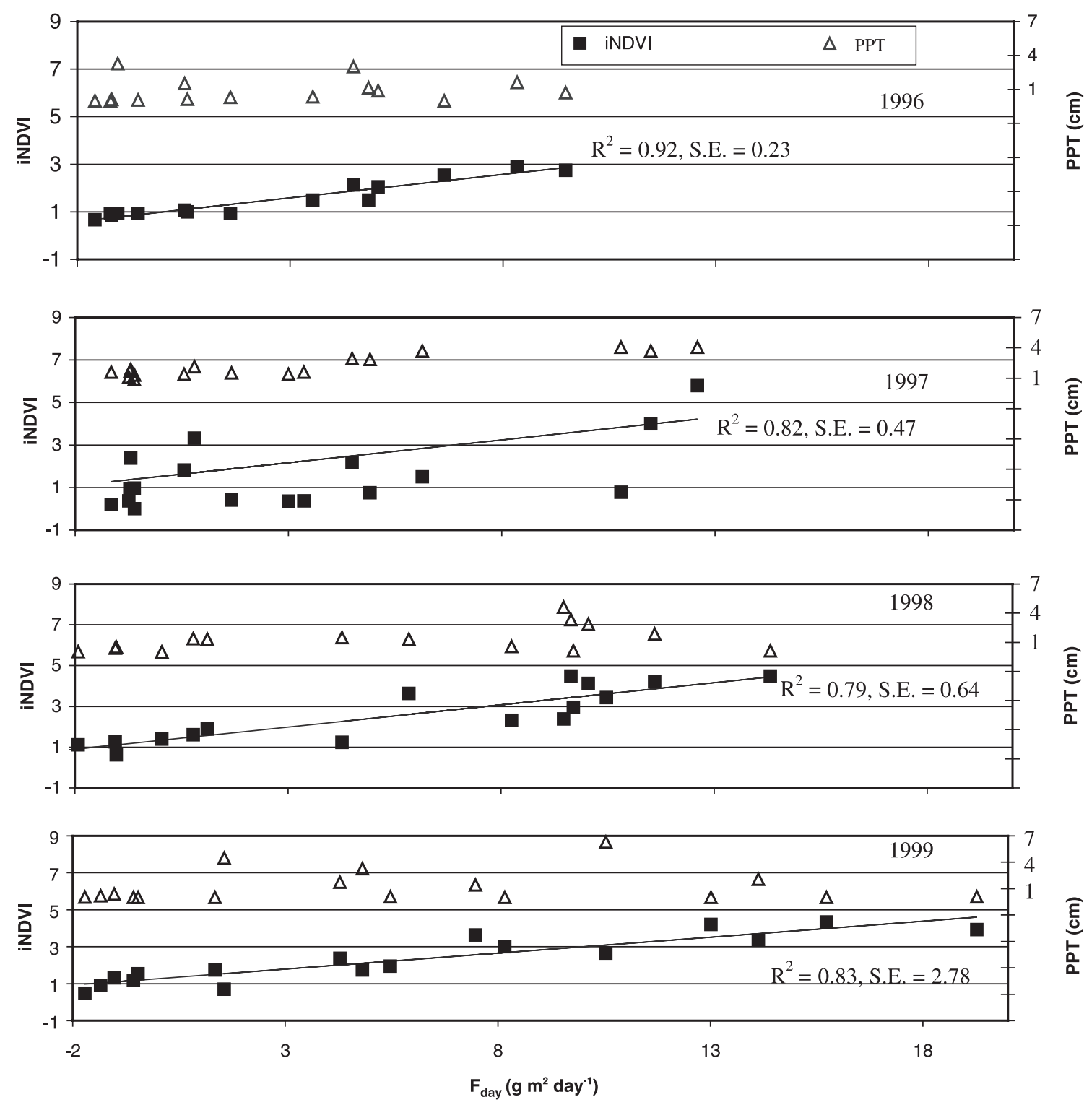

Fig. 2. Relationships between 14-day iNDVI, daytime $\mathrm{CO}_{2}$ flux ( $F_{\text {day }}$, and 14-day precipitation (PPT) for the 4 years of our study.

model. Inclusion of ET in the model may partially account for this phenomenon and possible variations in daytime $R$. Crossvalidation results (Table 2) indicated that both the

Table 2

Model statistics for biweekly regression and regression tree models used to estimate average 14-day diurnal $\mathrm{CO}_{2}$ flux $\left(F_{\text {day }} ; \mathrm{g} \mathrm{m}^{-2} \mathrm{C}\right)$ during the growing seasons of 1996-1999 $(n=66)$

\begin{tabular}{|c|c|c|c|c|}
\hline Model & $R^{2}$ & $R^{2}$ autocorrelation ${ }^{\mathrm{a}}$ & $R^{2}$ crossvalidation & $R^{2} 1999^{\mathrm{b}}$ \\
\hline NDVI & 0.79 & 0.62 & 0.79 & \\
\hline NDVI, $\mathrm{ET}^{\mathrm{c}}$ & 0.82 & 0.69 & 0.81 & 0.88 \\
\hline Regression tree ${ }^{\mathrm{d}}$ & 0.85 & & 0.77 & \\
\hline
\end{tabular}

\footnotetext{
${ }^{\text {a }}$ Temporal autocorrelation significant $(P<0.01)$ and corrected for.

${ }^{\mathrm{b}}$ Accounts for 1999 significantly different slopes and intercept coefficients with indicator and interaction terms.

${ }^{\mathrm{c}}$ Multicollinearity not a concern with a condition number of $8<30$ (Freund \& Littell, 1995).

${ }^{\mathrm{d}}$ Not tested for temporal autocorrelation.
}

simple iNDVI model and the iNDVI-ET model performed similarly. Because these relationships were developed for only one location, these relationships need to be examined and tested at other locations.

If several flux towers were to be operated across several years in the same ecosystem across the landscape, confidence in the representativeness of the training samples to the population would increase and should improve the robustness of spatial predictions. The target population, however, would necessarily be spatially constrained by the ecoregion boundary and the particular land cover at the measurement site. Resulting spatial and temporal predictions would allow monitoring and assessment of arid and semiarid rangeland ecosystems where the spatial and temporal variation of both rainfall and plant production can be high. Comparisons with other predictions of NEE and photosynthesis (Cohen \& Justice, 1999) could identify areas that require ground 

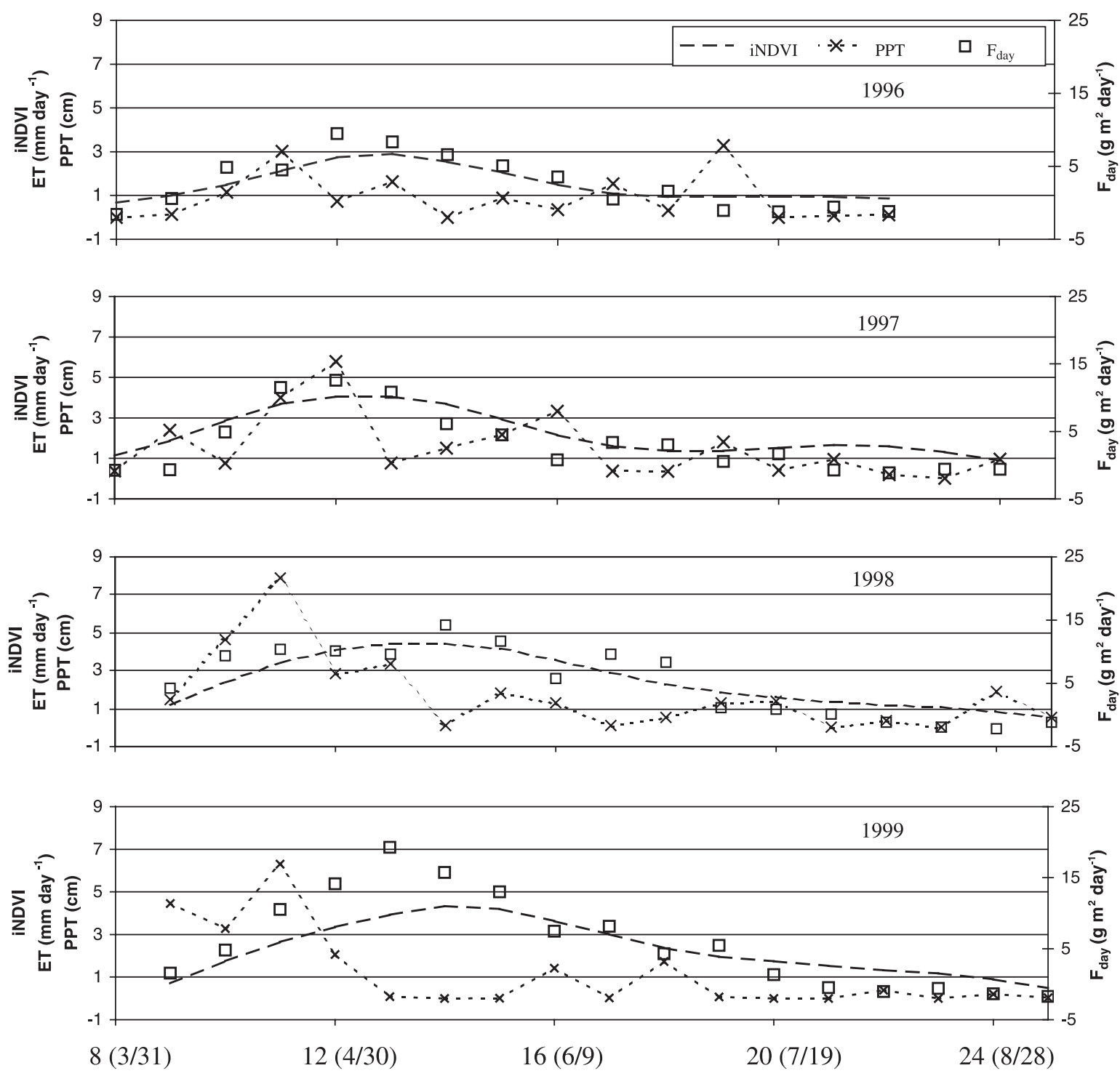

Biweekly Period (Date)

Fig. 3. Seasonal trends of 14-day iNDVI, evapotranspiration (ET), daytime $\mathrm{CO}_{2}$ flux ( $F_{\text {day }}$ ), and precipitation (PPT) for the 4 years of our study.

validation or further investigation. Inclusion of MODIS spatial and temporal estimates of LAI and fPAR could further improve $\mathrm{CO}_{2}$ flux predictions, but such estimates are only available beginning in 2000 .

Regression tree analysis was used to produce a regression tree model with a slightly higher $R^{2}$ value $(0.85$; Table 2). Crossvalidation with the regression tree analysis had a lower $R^{2}$ value (0.77), indicating that the regression tree model may have had some overfitting, which reduced robustness. Regression tree models perform better than linear regressions on large data sets that exhibit complex, nonlinear relationships and have interaction effects (De'ath \& Fabricius, 2000). In this case, a strong overall linear relationship existed in the data.

These results indicated that iNDVI provided useful prediction information about the Dubois site, which was improved with the inclusion of ET in the model. The addition of meteorological variables should allow refinement of the iNDVI and $F_{\text {day }}$ relationship to reflect variations of RUE and daytime respiration. At this site, about $79 \%$ of the variation in $F_{\text {day }}$ was explained by iNDVI. Remote sensing may complement gap-filling techniques for $F_{\text {day }}$ when data gaps span large time frames, or where other techniques may be forced to extrapolate rather than interpolate. These algorithms also could provide estimates for other sites with similar characteristics.

\subsection{Nighttime $\mathrm{CO}_{2}$ flux $\left(R_{n}\right)$}

Similar analyses were conducted to estimate $R_{\mathrm{n}}$ (Table 3). None of the $R_{\mathrm{n}}$ regression models had significant year effects. ET was the best single predictor of $R_{\mathrm{n}}$, which 
Table 3

Model statistics for biweekly regression and regression tree models estimating average 14-day nighttime $\mathrm{CO}_{2}$ flux $\left(R_{\mathrm{n}} ; \mathrm{g} \mathrm{m}^{-2} \mathrm{C}\right)$ for the growing seasons of 1996-1999 $(n=66)$

\begin{tabular}{llll}
\hline Model & $R^{2}$ & $R^{2}$ autocorrelation $^{\text {a }}$ & $R^{2}$ crossvalidation $^{2}$ \\
\hline ET & 0.53 & 0.46 & 0.52 \\
ET, PPT, TAIR, & $0.75^{\mathrm{b}}$ & & 0.66 \\
$\quad$ VPD, WINDS & & & 0.71 \\
Regression tree $^{\mathrm{c}}$ & 0.77 & &
\end{tabular}

${ }^{a}$ Temporal autocorrelation significant $(P<0.01)$ and corrected for.

${ }^{\mathrm{b}}$ Multicollinearity not a concern with a condition number of $8<30$ (Freund \& Littell, 1995).

${ }^{\mathrm{c}}$ Not tested for temporal autocorrelation.

outperformed iNDVI $\left(R^{2}=0.34\right)$ and accounted for about half the variability in $R_{\mathrm{n}}$. Similar $R^{2}$ values for the overall model and the crossvalidation modeling indicated this model was reasonably robust. Actual ET measured by the flux tower (ET) consists of evaporation and plant transpiration components. In this sagebrush-steppe ecosystem, ET was more strongly associated with iNDVI, NR, and PAR $\left(R^{2}=0.74,0.74\right.$, and 0.62$)$ than air temperature (TAIR) and vapor pressure deficit VPD $\left(R^{2}=0.44\right.$ and 0.19$)$. The transpiration component of ET is likely more significant than the evaporation component in this ecosystem because iNDVI, net radiation (NR), and PAR are related to photosynthesis. This supports observed relationships with livecanopy biomass and $R$ observed in rangelands of Inner Mongolia (Li et al., 2002).

The multiple regression relationship accounted for $75 \%$ of the variation in $R_{\mathrm{n}}$, and crossvalidation indicated that this relationship was robust (Table 3). The selected independent variables in Table 3 were listed in order of relevancy with ET being the most relevant. Temperature has an important impact on $R_{\mathrm{n}}$ and was the third most relevant variable. However, there was no simple linear or nonlinear relationship between TAIR and $R_{\mathrm{n}}\left(R^{2}=0.12\right)$. Moisture availability was important for soil respiration processes. The variables in the multiple regression analysis that were related to soil moisture were PPT, VPD, and ET. The least relevant variable, WINDS, plays an important role in $\mathrm{CO}_{2}$ fluxes affecting fetch area and mixing effects between the soil and atmosphere.

The regression tree model used only ET for stratification and eight variables to predict $R_{\mathrm{n}}$ (Table 4 ). The two most consistently used, highly relevant variables were associated with light availability (NR and PAR) followed by several variables associated with moisture [soil water content (SOILW) and VPD]. PPT, which was used in the multiple regression, was not used by the regression tree, and iNDVI was only slightly used. Crossvalidation indicated that regression tree models would have better prediction accuracies on withheld test data from this site $\left(R^{2}=0.71\right.$; Table 3$)$. Prediction of $R_{\mathrm{n}}$ was more complex than prediction of $F_{\text {day }}$, and the lack of a strong overall linear relationship resulted in the regression tree models having the best predictability. These techniques for estimating $F_{\text {day }}$ and $R_{\mathrm{n}}$, if developed from
Table 4

Regression tree variables used to stratify and predict average 14-day nighttime $\mathrm{CO}_{2}$ flux $\left(R_{\mathrm{n}} ; \mathrm{g} \mathrm{m}^{2} \mathrm{C}\right)$

\begin{tabular}{lcl}
\hline Variables & $\begin{array}{l}\text { Stratification } \\
(\% \text { utilization })\end{array}$ & $\begin{array}{l}\text { Prediction } \\
\text { weight }\end{array}$ \\
\hline NR & 0 & 0.9 \\
PAR & 0 & 0.9 \\
SOILW & 0 & 0.5 \\
VPD & 0 & 0.5 \\
ET & 100 & 0.4 \\
TAIR & 0 & 0.3 \\
WINDS & 0 & 0.3 \\
iNDVI & 0 & 0.2 \\
\hline
\end{tabular}

multiple sites and years, would allow large area mapping of the seasonal dynamics of $F_{\text {day }}$ and $R_{\mathrm{n}}$. In addition, large area assessment of $F_{\text {net }}$ could allow the monitoring of $\mathrm{CO}_{2}$ fluxes that incorporate spatial and temporal dynamics present in arid and semiarid rangeland ecosystems.

\subsection{Mobile tower simulation}

If periodic rather than continuous measurements of $F_{\text {day }}$ could be used in combination with iNDVI data to accurately predict $\mathrm{CO}_{2}$ fluxes, then it may be possible to collect $F_{\text {day }}$ and $R_{\mathrm{n}}$ flux data across multiple sites with a single mobile flux tower. This might improve the accuracy of both mechanistic and statistical models that estimate $F_{\text {day }}, R_{\mathrm{n}}$, or NEE. Mobile towers also might allow an assessment of $\mathrm{CO}_{2}$ fluxes and, in combination with remote sensing, may better account for temporal variations in $\mathrm{CO}_{2}$ fluxes and thereby provide more accurate assessments of $F_{\text {day }}$ across landscape or regional levels. Such an approach may allow a single flux tower to accurately monitor $\mathrm{CO}_{2}$ fluxes at several sites, maximizing the utility of expensive flux towers. This may allow evaluations of different management treatments, carbon certification at several sites, and more effective parameterization and validation of $\mathrm{CO}_{2}$ flux models.

Regression coefficients were quite stable across all three sequence periods for the simple regression between $F_{\text {day }}$ and iNDVI (Table 5). Temporal autocorrelation was not significant $(P<0.05)$ in any of the sequence regressions. Most variability occurred in the slope coefficient, and the confidence interval for all observations overlapped the slope estimates for the three sequence periods. This and the magnitudes of the standard errors of the regression indicated that reasonably accurate and unbiased estimates of $F_{\text {day }}$

Table 5

Model statistics for the three time sequences and all observations pooled for daytime $\mathrm{CO}_{2}$ flux $\left(F_{\text {day }}\right)$ regressed on iNDVI

\begin{tabular}{lllllll}
\hline Sequence & Intercept & S.E. & Slope & S.E. & $R^{2}$ & $\begin{array}{l}\text { S.E. } \\
\text { regression }\end{array}$ \\
\hline 1 & -4.06 & 1.07 & 3.76 & 0.43 & 0.79 & 2.38 \\
2 & -4.80 & 1.00 & 4.34 & 0.41 & 0.85 & 2.24 \\
3 & -4.16 & 1.26 & 4.01 & 0.52 & 0.75 & 2.83 \\
All & -4.34 & 0.63 & 4.04 & 0.26 & 0.79 & 2.44 \\
\hline
\end{tabular}


Table 6

Multiple regression parameters for estimating daytime $\mathrm{CO}_{2}$ flux $\left(F_{\text {day }}\right)$ from iNDVI and evapotranspiration (ET) for three time sequences and all observations pooled

\begin{tabular}{llllll}
\hline Sequence & Intercept & $\begin{array}{l}\text { Slope } \\
\text { NDVI }\end{array}$ & $\begin{array}{l}\text { Slope } \\
\text { ET }\end{array}$ & $R^{2}$ & $\begin{array}{l}\text { S.E. } \\
\text { regression }\end{array}$ \\
\hline $1^{\mathrm{a}}$ & -3.90 & 3.23 & 0.51 & 0.79 & 2.41 \\
$2^{\mathrm{a}}$ & -4.28 & 2.70 & 1.56 & 0.89 & 1.93 \\
$3^{\mathrm{a}}$ & -3.76 & 2.23 & 1.84 & 0.80 & 2.61 \\
All observations $^{\mathrm{b}}$ & -3.93 & 2.96 & 1.01 & 0.86 & 2.06 \\
\hline
\end{tabular}

${ }^{\text {a }}$ Autocorrelation not significant $(P<0.01)$.

${ }^{\mathrm{b}}$ Corrected for first-order temporal autocorrelation.

would be obtained with iNDVI and periodic $F_{\text {day }}$ measurements with a repeat cycle of every 6 weeks. Continuous flux measurements provided only a minor improvement in the standard error of the regression.

The parameters for the multiple regression relationships with iNDVI and ET were also robust across the three sequence periods, and regression coefficients for the individual sequence periods overlapped with those derived from all observations (Table 6). These results indicated that periodic measurements of $F_{\text {day }}$, as provided by mobile towers, could be used to accurately assess $F_{\text {day }}$ with only minimal losses in flux information. Mobile flux measurements could also provide a spatial assessment of $\mathrm{CO}_{2}$ fluxes by allowing three times the number of locations to be monitored with the same equipment.

\section{Summary}

Subdividing NEE or $F_{\text {net }}$ into components of $F_{\text {day }}$ and $R_{\mathrm{n}}$ allowed predictive models to be developed for both $F_{\text {day }}$ and $R_{\mathrm{n}}$. These component models for predicting $F_{\text {day }}$ and $R_{\mathrm{n}}$ are more functionally based than a model for predicting NEE. Remotely sensed iNDVI alone or iNDVI, in combination with ET, was a strong predictor of biweekly values of $F_{\text {day }}$. This suggests that iNDVI is an important driver to consider for regional mapping of $F_{\text {day }} \mathrm{CO}_{2}$ fluxes. Regression tree models provided robust predictions of $R_{\mathrm{n}}$. Combining estimates of $F_{\text {day }}$ and $R_{\mathrm{n}}$ may be useful in accounting for both temporal and spatial effects on carbon source and sink relationships in highly variable arid and semiarid rangeland ecosystems. This mapping also would be useful in determining the necessary timing and locations for monitoring various management scenarios for carbon sequestration. Mobile rather than stationary flux towers may allow a better spatial representation of regional $\mathrm{CO}_{2}$ fluxes and facilitate spatial extrapolation of fluxes with minimal loss of accuracy from site-specific flux measurements.

\section{Acknowledgements}

This work was performed, in part, by the US. Geological Survey, EROS Data Centre contract 1434-CR-97CN-40274 with Raytheon Systems Company. Additional support for this research came from the Global Livestock Collaborative Research Support Program funded by USAID grant PCE-G00-98-00036-00.

\section{References}

Angell, R. F., Svejcar, T., Bates, J., Saliendra, N. Z., \& Johnson, D. A. (2001). Bowen ratio and closed chamber carbon dioxide flux measurements over sagebrush steppe vegetation. Agricultural and Forest Meteorology, 108, 153-161.

Anthoni, P. M., Law, B. E., \& Unsowrth, M. H. (1999). Carbon and water vapor exchange of an open-canopied ponderosa pine ecosystem. Agricultural and Forest Meteorology, 95, 115-168.

Asner, G. P., Bateson, C. A., Privette, J. L., El Saleous, N., \& Wessman, C. A. (1998). Estimating vegetation structural effects on carbon uptake using satellite data fusion and inverse modeling. Journal of Geophysical Research, 103(D22), 28839-28853.

Asner, G. P., \& Wessman, C. A. (1997). Scaling PAR absorption from the leaf to landscape level in spatially heterogeneous ecosystems. Ecological Modeling, 103, 81-97.

Aubinet, M., Grelle, A., Ibrom, A., Rannik, U., Moncrieff, J., Foken, T., Kowalski, A. S., Martin, P. H., Berbigier, P., Bernhofer, C., Clement, R., Elbers, J., Granier, A., Grunwald, T., Morgenstern, K., Pilegaard, K., Rebmann, C., Snijders, W., Valentini, R., \& Vesala, T. (2000). Estimates of the annual net carbon and water exchange of forest: the EUROFLUX methodology. Advances in Ecological Research, 30, 113-175.

Bajracharya, R. M., Lal, R., \& Kimbal, J. M. (2000). Diurnal and seasonal $\mathrm{CO}_{2}$ flux from soil as related to erosion phases in central Ohio. Soil Science Society of America Journal, 64, 286-293.

Baldocchi, D. D., Verma, S. B., \& Rosenberg, N. J. (1981). Mass and energy exchanges of a soybean under various environmental regimes. Agronomy Journal, 73, 706-710.

Bartlett, D. S., Whitting, G. J., \& Hartman, J. M. (1990). Use vegetation indices to estimate intercepted solar radiation and net carbon dioxide exchange of a grass canopy. Remote Sensing of Environment, 30 , $115-128$.

Biondini, M. E., Lauenroth, W. K., \& Sala, O. E. (1991). Correcting estimates of net primary production: are we overestimating plant production in rangelands? Journal of Range Management, 44, 194-198.

Blaisdell, J. P. (1958). Seasonal development and yield of native plants on the upper Snake River Plains and their relation to certain climatic factors. USDA technical bulletin, vol. 1190 (pp. 1-68). Washington, DC, U.S. Govt. Print Off.: USDA. 68 pp.

Bliss, N. B., Waltman, S. W., \& Petersen, G. W. (1995). Preparing a soil inventory for the United States using geographic information systems. In R. Lal, J. Kimble, E. Levine, \& B. A. Stewart (Eds.), Soils and global change (pp. 275-295). Florida: CRC Press.

Bonan, G. B. (1995). Land-atmosphere interactions for climate system models: coupling biophysical, biogeochemical, and ecosystem dynamical processes. Remote Sensing of Environment, 51, 57-73.

Bounoua, L., Cooatz, G. J., Los, S. O., Sellers, P. J., Dazlich, D. A., Tucker, C. J., \& Randall, D. A. (2000). Sensitivity of climate to changes in NDVI. Journal of Climate, 13, 2277-2292.

Bristow, K. L., \& Campbell, G. S. (1984). On the relationship between incoming solar radiation and daily maximum and minimum temperature. Agricultural and Forest Meteorology, 31, 159-166.

Cairns, D. M. (2001). A comparison of methods for predicting vegetation type. Plant Ecology, 156, 3-18

Caselles, V. (1993, September). Mapping actual evapotranspiration by combining Landsat-TM and NOAA-AVHRR images. In T. Carlson, O. Taconet, A. Vidal, S. Moran, \& R. Gillies (Eds.), Workshop on thermal remote sensing of energy and water balance over vegetation 
in conjunction with other sensors, La Londe les Maures, France (pp. 309-312). University Park, PA: Pennsylvania State University.

Chen, D., \& Brutsaert, W. (1998). Satellite-sensed distribution and spatial patterns of vegetation parameters over a tallgrass prairie. Journal of the Atmospheric Sciences, 55, 1225-1238.

Chen, J. M. (1996). Canopy architecture and remote sensing of the fraction of photosynthetically active radiation absorbed by boreal conifer forests. IEEE Transactions on Geoscience and Remote Sensing, 34, $1353-1368$

Choudhury, B. J. (2000). A sensitivity analysis of the radiation use efficiency for gross photosynthesis and net carbon accumulation by wheat. Agricultural and Forest Meteorology, 101, 217-234.

Choudhury, B. J. (2001). Estimating gross photosynthesis using satellite and ancillary data. Remote Sensing of Environment, 75, 1-21.

Choudhury, B. J., \& DiGirolamo, N. E. (1998). A biophysical processbased estimate of global land surface evaporation using satellite and ancillary data: I. Model description and comparisons with observations. Journal of Hydrology, 205, 164-185.

Cihlar, J., Caromori, P. H., Schuepp, P. H., Desjardins, T. L., \& MacPherson, J. L. (1992). Relationships between satellite-derived indices and aircraft-based measurements. Journal of Geophysical Research, 97, $18522-18525$.

Cihlar, J., Denning, S., Ahern, F., Arino, O., Belward, A., Bretherton, F., Cramer, W., Dedien, G., Field, C., Francey, R., Gommes, R., Gosz, J., Hibbard, K., Igarashi, T., Kabat, P., Olsen, D., Plummer, S., Rasool, I., Raupach, M., Scholes, R., Townsend, J., Valentini, R., \& Wickland, D. (2002). Initiative to quantify terrestrial carbon sources and sinks. EOS, Transactions of the American Geophysical Union, 83, 1-7.

Cohen, W. B., \& Justice, C. O. (1999). Validating MODIS terrestrial ecology products: linking in situ and satellite measurements. Remote Sensing of Environment, 70, 1-3.

De'ath, G., \& Fabricius, K. E. (2000). Classification and regression trees: a powerful yet simple technique for ecological data analysis. Ecology, 81, $3178-3192$.

Desjardins, R. L., Hart, R. L., Macpherson, J. L., Schuepp, P. H., \& Verma, S. B. (1992). Aircraft-based and tower-based fluxes of carbon-dioxide, latent, and sensible heat. Journal of Geophysical Research: Atmospheres, 97, 18477 .

Dugas, W. A. (1993). Micrometeorological and chamber measurements of $\mathrm{CO}_{2}$ flux from bare soil. Agricultural and Forest Meteorology, 67, $115-128$.

Dugas, W. A., Fritschen, L. J., Gay, L. W., Held, A. A., Matthieas, A. D., Reicosky, D. C., Steduto, P., \& Steiner, J. L. (1991). Bowen ratio, eddy correlation, and portable chamber measurements of sensible and latent heat flux over irrigated spring wheat. Agricultural and Forest Meteorology, 56, 1-20.

Dugas, W. A., Heuer, M. L., \& Mayeux, H. S. (1999). Carbon dioxide fluxes over Bermuda grass, native prairie, and sorghum. Agricultural and Forest Meteorology, 93, 121-139.

Falge, E., Baldocci, D., Olsen, R., Anthoni, P., Aubinet, M., Bernhofer, C., Burba, G., Ceulemans, R., Clement, R., Dolman, H., Franier, A., Gross, P., Grunwald, T., Hollinger, D., Jensen, N., Katul, G., Keronen, P., Kowalski, A., Lai, C. T., Law, B. E., Meyers, T., Moncrieff, J., Moors, E., William Munger, J., Pilegaard, K., Rannik, U., Rebmann, C., Suyker, A., Tenhunen, J., Tu, K., Verma, S., Vesala, T., Wilson, K., \& Wofsy, S. (2001). Gap filling strategies for defensible annual sums of net ecosystem exchange. Agricultural and Forest Meteorology, 107, $43-69$.

Fallon, P. D., Smith, P., Smith, J. U., Szabo, J., Coleman, K., \& Marshall, S. (1998). Regional estimates of carbon sequestration potential: linking the Rothamsted Carbon Model to GIS databases. Biology and Fertility of Soils, 27, 236-241.

Field, C. B., Gamon, J. A., \& Penuelas, J. (1994). Remote sensing of terrestrial photosynthesis. In E. D. Schulze, \& M. M. Caldwell (Eds.), Ecophysiology of photosynthesis. Ecological studies, vol. 100 (pp. 511-527). Berlin, Germany: Springer-Verlag.

Field, C. B., Randerson, J. T., \& Malmstrom, C. M. (1995). Global net primary production: combining ecology and remote sensing. Remote Sensing of Environment, 51, 74-88.

Frank, A. B., \& Dugas, W. A. (2001). Carbon dioxide fluxes over a northern, semiarid, mixed-grass prairie. Agricultural Meteorology, $108,127-317$

Freund, R. J., \& Littell, R. C. (1995). Choosing useful models. SAS system for regression (2nd ed.). SAS series in statistical applications (pp. 109-114). Cary, NC: SAS Institute.

Gamon, J. A., Field, C. B., Goulden, M. L., Griffin, K. L., Hartley, A. E., Joel, G., Penuelas, J., \& Valentini, R. (1995). Relationships between NDVI, canopy structure, and photosynthesis in three California vegetation types. Ecological Applications, 5, 28-41.

Gilabert, M. A., Masellin, F., Conese, C., \& Bindi, M. (1995). Characterization of primary productivity levels of Niger by means of NOAA NDVI variations. Geocarto International, 10, 31-41.

Gilmanov, T. G., Johnson, D. A., \& Saliendra, N. Z. (2003). Growing season $\mathrm{CO}_{2}$ fluxes in a sagebrush-steppe ecosystem in Idaho: Bowen ratio/energy balance measurements and modeling. Basic and Applied Ecology, 4(2), 167-183.

Gilmanov, T. G., \& Oechel, W. C. (1995). New estimates of organic matter reserves and net primary productivity of the North American tundra ecosystems. Journal of Biogeography, 22, 723-741.

Gilmanov, T. G., Parton, W. J., \& Ojima, D. J. (1997). Testing the 'CENTURY' ecosystem level model on data sets from eight grassland sites in the former USSR representing a wide climatic/soil gradient. Ecological Modeling, 96, 191-210.

Glardina, C. P., \& Ryan, M. G. (2000). Evidence that decomposition rates of organic carbon in mineral soil do not vary with temperature. Nature, $404,858-861$

Gower, S. T., Kucharik, C. J., \& Norman, J. M. (1999). Direct and indirect estimation of leaf area index, fAPAR, and net primary production of terrestrial ecosystems. Remote Sensing of Environment, 70, 29-51.

Gustavsson, L., Karjalainen, T., Marland, G., Savolainen, I., Schlamadinger, B., \& Apps, M. (2000). Project-based greenhouse-gas accounting: guiding principles with a focus on baselines and additionality. Energy Policy, 28, 935-946.

Hall, F. G., Knapp, D. E., \& Huemmrich, K. F. (1997). Physically based classification and satellite mapping of biophysical characteristics in the southern boreal forest. Journal of Geophysical Research, 102(D24), $29567-29580$.

Hall, F. G., Townshend, J. R., \& Engman, E. T. (1995). Status of remote sensing algorithms for estimation of land surface parameters. Remote Sensing of Environment, 51, 138-156.

Hanan, N. P., Prince, S. D., \& Begue, A. (1995). Estimation of absorbed photosynthetically active radiation and vegetation net production efficiency using satellite data. Agricultural and Forest Meteorology, 76, 259-276.

Hanan, N. P., Prince, S. D., \& Begue, A. (1997). Modeling vegetation primary production during HAPEX-Sahel using production efficiency and canopy conductance model formulations. Journal of Hydrology, $188-189,651-657$

Hunt Jr., E. R., Lavigne, M. B., \& Franklin, S. E. (1999). Factors controlling the decline of net primary production with stand age for balsam fir in Newfoundland assessed using an ecosystem simulation model. Ecological Modeling, 122, 151-164.

Jamieson, P. D., Martin, R. J., Francis, G. S., \& Wilson, D. R. (1995). Drought effects on biomass production and radiation-use efficiency in barley. Field Crops Research, 43, 77-86.

Joel, M., Schimel, D. S., Friedl, M. A., Davis, F. W., \& Dubayah, R. C. (1994). Regression tree analysis of satellite and terrain data to guide vegetation sampling and surveys. Journal of Vegetation Science, 5 , $673-689$

Kelly, R. D., Hunt Jr., E. R., Reiners, W. A., Smith, W. K., \& Welker, J. M. (2002). Relationships between daytime carbon dioxide uptake and absorbed photosynthetically active radiation for three different mountain/ plains ecosystems. Journal of Geophysical Research: Atmospheres (DOI 10.1029/2001JD001181) 
Kim, J., Verma, S. B., \& Rosenberg, N. J. (1989). Energy balance and water use in cereal crops. Agricultural and Forest Meteorology, 48, $135-147$.

Kimball, J. S., Running, S. W., \& Nemani, R. (1997). An improved method for estimating surface humidity from daily minimum temperature. Agricultural and Forest Meteorology, 85, 87-98.

Knyazikhin, Y., Glassy, J., Privette, J. L., Tian, Y., Lotsch, A., Zhang, Z., Wang, Y., Morisette, J. T., Votava, P., Myneni, R. B., Nemani, R. R., \& Running, S. W. (1999). MODIS leaf area index (LAI) and fraction of photosynthetically active radiation absorbed by vegetation (FPAR) product (MOD15) algorithm theoretical basis document (http://eospso. gsfc.nasa.gov/atbd/modistables.html).

Kohlmaier, G. H., Badeck, F. W., Otto, R. D., Hager, C., Donges, S., Kindermann, J., Wurth, G., Lang, T., Jakel, U., Nadler, A., Ramge, P., Klaudius, A., Habermehl, S., \& Ludeke, M. K. B. (1997). The Frankfurt biosphere model: a global process-oriented model of seasonal and long-term $\mathrm{CO}_{2}$ exchange between terrestrial ecosystems and the atmosphere: II. Global results for potential vegetation in an assumed equilibrium state. Climate Research, 8, 61-87.

Law, B. E., Williams, M., Anthoni, P. M., Baldocchi, D. D., \& Unsworth, M. H. (2000). Measuring and modeling seasonal variation of carbon dioxide and water vapor exchange of Pinus ponderosa forest subject to soil water deficit. Global Change Biology, 6, 613-630.

Li, L. -H., Zhang, Y., Yang, J., Yan, Z. -D., Li, X., Bai, W. -M., Song, S. -H., Han, X. G., Wang, Q. -B., \& Chen, Q. -S. (2002). Correlations between plant biomass and soil respiration in a Leymus chinesis community in the Xilin River basin of Inner Mongolia. Acta Botanica Sinica, 44, 593-597.

Liu, L., Chen, J. M., Cihlar, J., \& Chen, W. (2002). Net primary productivity mapped for Canada at $1 \mathrm{Km}$ resolution. Global Change and Biogeography, 11, 115-129.

Loechel, S. E., Walthall, C. L., Brown de Colstoun, E., Chen, J., Markham, B. L., \& Miller, J. (1997). Variability of boreal forest reflectances as measured from a helicopter platform. Journal of Geophysical Research, 102, 29495-29503.

Lopez, G., Rubio, M. A., Martinez, M., \& Batlles, F. J. (2001). Estimation of hourly global photosynthetically active radiation using artificial neural network model. Agricultural and Forest Meteorology, 107, $279-291$

Los, S. O., Justice, C., \& Tucker, C. J. (1994). A global 1 degree by 1 degree NDVI data set for climate studies derived from the GIMMS continental NDVI data. International Journal of Remote Sensing, 15, 3493-3518.

Mack, A. R., Desjardins, R. L., MacPherson, J. I., \& Schuepp, P. H. (1990). Relative photosynthetic activity of agricultural lands from airborne carbon dioxide and satellite data. International Journal of Remote Sensing, $11,237-251$.

Massman, W. J., Sommerfeld, R. A., Mosier, A. R., \& Zeller, K. F. (1997). A model investigation of turbulence-driven pressure-pumping effects on the rate of diffusion of $\mathrm{CO}_{2}, \mathrm{~N}_{2} \mathrm{O}$, and $\mathrm{CH}_{4}$ through layered snowpacks. Journal of Geophysical Research, 102, 18851-18863.

Mielnick, P. C., \& Dugas, W. A. (2000). Soil $\mathrm{CO}_{2}$ flux in a tallgrass prairie. Soil Biology and Biochemistry, 32, 221-228.

Moncrieff, J., Valentini, R., Greco, S., Seufert, G., \& Ciccioli, P. (1997). Trace gas exchange over terrestrial ecosystems: methods and perspectives in micrometeorology. Journal of Experimental Botany, 48, $1133-1142$.

Monteith, J. L. (1977). Climate and the efficiency of crop production in Britain. Philosophical Transactions of the Royal Society of London, B, 281, 277-294.

Natural Resource Conservation Service [NRCS] (1995). Soil investigation of ARS United States Experimental Station headquarters range. Rexburg, ID, USA: U.S. Department of Agriculture, NRCS.

Neter, J., Wasserman, W., \& Kutner, M. H. (1983). Applied linear regression models p. 547. Illinois: Richard D. Irwin.

NOAA (1993). Climatological data annual summary-Idaho. NOAA Report, 96(13).
Oechel, W. C., Vourlitis, G., Verfaillier Jr. J., Crawford, T., Brooks, S., Dumas, E., Hope, A., Stow, D., Boynton, B., Nosov, V., \& Zulueta, T. (2000). A scaling approach for quantifying the net $\mathrm{CO}_{2}$ flux of the Kuparuk River Basin, Alaska. Global Change: Biology, 6, 160-173.

Pan, Y., Melillo, J. M., McGuire, A. D., Kicklighter, D. W., Pitelka, L. F., Hibbard, K., Pierce, L. L., Running, S. W., Ojima, D. S., Parton, W. J., \& Schimel, D. S. (1998). Modeled responses of terrestrial ecosystems to elevated atmospheric $\mathrm{CO}_{2}$ : a comparison of simulations by the biogeochemistry models of the Vegetation/Ecosystem Modeling and Analysis Project (VEMAP). Oecologia, 114, 389-404.

Parizek, B., Rostagno, C. M., \& Sottini, R. (2002). Soil erosion as affected by shrub encroachment in northeastern Patagonia. Journal of Range Management, 55, 43-48.

Paruelo, J. M., Epstein, H. E., Lauenroth, W. K., \& Burke, I. C. (1997) ANPP estimates from NDVI for the central grassland region of the United States. Ecology, 78, 953-959.

Pfaff, A. S. P., Kerr, S., Hughes, R. F., Liu, S., Sanchez-Azofeifa, G. A., Schimel, D., Tosi, J., \& Watson, V. (2000). The Kyoto Protocol and payments for tropical forest: an interdisciplinary method for estimating carbon-offset supply and increasing the feasibility of a carbon market under the CDM. Ecological Economics, 35, 203-221.

Potter, C. S., Randerson, J. T., Field, C. B., Matson, P. A., Vitousek, P. M., Mooney, H. A., \& Klooster, S. A. (1993). Terrestrial ecosystem production: a process model based on global satellite and surface data. Global Biogeochemical Cycles, 7, 811-841.

Prince, S. D., \& Steininger, M. K. (1999). Biophysical stratification of the Amazon Basin. Global Change Biology, 5, 1-22.

Purevdorj, T., Tateishi, R., Ishiyama, T., \& Honda, Y. (1998). Relationships between percent vegetation cover and vegetation indices. International Journal of Remote Sensing, 19, 3519-3535.

Rahman, A. F., Gamon, J. A., Fuentes, D. A., Roberts, D. A., \& Prentiss, D. (2001). Modeling spatially distributed ecosystem flux of boreal forest using hyperspectral indices from AVIRIS imagery. Journal of Geophysical Research, 106, 33579-33591.

Raich, J. W., Potter, C. S., \& Bhagawati, D. (2002). Interannual variability in global soil respiration. Global Change Biology, 8, 800-812.

Randall, D. A., Dazlich, D. A., Zhang, C., \& Denning, A. S. (1996). A revised land surface parameterization (SIB2) for GCMs: Part III. The greening of the Colorado State University General Circulation Model. Journal of Climate, 9, 738-763.

Raupach, M. R. (1988). Canopy transport processes. In W. L. Steffen, \& O. T. Denmead (Eds.), Flow and transport in the natural environment: advances and applications (pp. 95-127). Berlin: Springer-Verlag.

Reed, B. C., Brown, J. F., VanderZee, D., Loveland, T. L., Merchant, J. W., \& Ohlen, D. O. (1994). Measuring phenological variability from satellite imagery. Journal of Vegetation Science, 5, 703-714.

Reeves, M. C., Winslow, J. C., \& Running, S. W. (2001). Mapping weekly rangeland vegetation productivity using MODIS algorithms. Journal of Range Management, 54, 207. Available at: http://uvalde.tamu.edu/jrm/ remote/index.htm.

Reich, P. B., Turner, D. P., \& Bolstad, P. (1999). An approach to spatially distributed modeling of net primary production (NPP) at the landscape scale and its application in validation of EOS NPP products. Remote Sensing of Environment, 70, 69-81.

Rosenberg, N. J. (1983). Microclimate: the biological environment. New York: Wiley.

Running, S. W., Baldocchi, D. D., Turner, D. P., Gower, S. T., Bakwin, P. S., \& Hibbard, K. A. (1999). A global terrestrial monitoring network integrating tower fluxes, flask sampling, ecosystem modeling and EOS satellite data. Remote Sensing of Environment, 70, 108-127.

Seen, L. D., Mougin, E., Rambal, S., Gaston, A., \& Hiernaux, P. (1995). A regional Sahelian grassland model to be coupled with multispectral satellite data: II. Toward the control of its simulations by remotely sensed indices. Remote Sensing of Environment, 52, 194-206.

Sellers, P. J., Dickinson, R. E., Randall, D. A., Betts, A. K., Hall, F. G., Berry, J. A., Collatz, G. J., Denning, A. S., Mooney, H. A., Nobre, C. A., Sato, N., Field, C. B., \& Henderson-Sellers, A. (1997). Modeling the ex- 
changes of energy, water, and carbon between continents of the atmosphere. Science, 275, 502-509.

Sims, P. L., \& Bradford, J. A. (2001). Carbon dioxide fluxes in a southern plains prairie. Agricultural and Forest Meteorology, 109, 117-134.

Svejcar, T., Mayeux, H., \& Angell, R. (1997). The rangeland carbon dioxide flux project. Rangelands, 19, 16-18.

Swets, D. L., Reed, B. C., Rowland, J. R., \& Marko, S. E. (1999). A weighted least-squares approach to temporal smoothing of NDVI. 1999 ASPRS Annual Conference, From Image to Information, Portland, OR, May 17-21, 1999, Proceedings, American Society for Photogrammetry and Remote Sensing, Bethesda, MD [CD-ROM, one disc].

Takle, E. S., Brandle, J. R., Schmidt, R. A., Garcia, R., Litvina, I. V., Doyle, G., Zhou, X., Hou, Q., Rice, C. W., \& Massman, W. J. (2000). Pressure pumping of carbon dioxide from soil. 24th Conference on agricultural and forest meteorology (pp. 190-191). Boston: AMS.

Thornton, P. E., \& Running, S. W. (1999). An improved algorithm for estimating incident daily solar radiation from measurements of temperature, humidity, and precipitation. Agricultural and Forest Meteorology, 93, 211-228.

Tieszen, L. T., Reed, B. C., Bliss, N. B., Wylie, B. K., \& DeJong, D. D. (1997). NDVI, $C_{3}$ and $C_{4}$ production, and distributions in Great Plains grassland land cover classes. Ecological Applications, 7, 59-78.

Tucker, C. J., Fung, I. Y., Keeling, C. D., \& Gammon, R. H. (1986). Relationship between atmospheric $\mathrm{CO}_{2}$ variations and a satellite-derived vegetation index. Nature, 319, 195-199.

Tufekcioglu, A., Raich, J. W., Isenhart, T. M., \& Schultz, R. C. (2001). Soil respiration within riparian buffers and adjacent crop fields. Plant and Soil, 229, 117-124.

Turner, D. P., Gower, S. T., Stith, T., Cohen, W. B., Gregory, M., \& Maiersperger, T. K. (2002). Effects of spatial variability in light use efficiency on satellite-based NPP monitoring. Remote Sensing of Environment, 80, 379-406.

Twine, T. E., Kustas, W. P., Norman, J. M., Cook, D. R., Houser, P. R., Meyers, T. P., Prueger, J. H., Starks, P. J., \& Wesely, M. L. (2000). Correcting eddy-covariance flux underestimates over a grassland. Agricultural and Forest Meteorology, 103, 279-300.

Unland, H. E., Houser, P. R., Shuttleworth, W. J., \& Yang, Z. (1996). Surface flux measurement and modeling at a semi-arid Sonoran Desert site. Agricultural and Forest Meteorology, 82, 119-153.

Valentini, R., Gamon, J. A., \& Field, C. B. (1995). Ecosystem gas exchange in a California grassland: seasonal patterns and implications for scaling. Ecology, 76, 1940-1952.
Valentini, R., Matteucci, G., Dolman, A. J., Schulze, E. D., Rebmann, C., Moors, E. J., Granier, A., Gross, P., Jensen, N. O., Pilegaard, K., Lindroth, A., Grelle, A., Bernhofer, C., Grunwald, T., Aubinet, M., Ceulemans, R., Kowalski, A. S., Vesala, T., Rannik, U., Berdigier, P., Loustau, D., Guomundsson, J., Thorgeirsson, H., Ibrom, A., Morgenstern, K., Clement, R., Moncrieff, J., Montagnani, L., Minerbi, S., \& Jarvis, P. G. (2000). Respiration as the main determinant of carbon balance in European forests. Nature, 404, 861-865.

Verma, S. B., \& Rosenberg, N. J. (1975). Accuracy of lysimetric, energy balance, and stability corrected aerodynamic methods of estimating above-canopy flux of $\mathrm{CO}_{2}$. Agronomy Journal, 67, 699-704.

Vourlitis, G. L., Oechel, W. C., Hope, A., Stow, D., Boynton, B., Verfaillie Jr., J., Zulueta, R., \& Hastings, S. J. (2000). Physiological models for scaling plot measurements of $\mathrm{CO}_{2}$ flux across an arctic tundra landscape. Ecological Applications, 10, 60-72.

Webb, E. K., Pearman, G. I., \& Leuning, R. (1980). Correction of flux measurement for density effect due to heat and water vapor transfer. Quarterly Journal of the Royal Meteorological Society, 106, $85-100$.

West, N. E. (1983). Western intermountain sagebrush steppe. In N. E. West (Ed.), Ecosystems of the world: 5. Temperate deserts and semi-deserts (pp. 351-397). New York: Elsevier.

Williams, M., Eugster, W., Rastetter, E. B., McFadden, J. P., \& Chapin III, F. S. (2000). The controls on net ecosystem productivity along an Arctic transect: a model comparison with flux measurements. Global Change Biology, 6, 116-126.

Wylie, B. K. (1991). Herbaceous biomass assessment in the central pastoral zone of the Sahelian country of Niger 1986-1988 (pp. 1-98). PhD Dissertation. Las Cruces, NM: New Mexico State University.

Wylie, B. K., Harrington, J. A. Jr., Prince, S. D., \& Denda, I. (1991). Satellite and ground-based pasture production assessment in Niger: 1986-1988. International Journal of Remote Sensing, 12, 1281-1300.

Wylie, B. K., Meyer, D. J., Tieszen, L. L., \& Mannel, S. (2002). Satellite mapping of surface biophysical parameters at the biome scale over the North America grasslands: a case study. Remote Sensing of Environment, 79, 266-278.

Xie, P., \& Arkin, P. A. (1997). A 17-year monthly analysis based on gauge observations, satellite estimates, and numerical model outputs. Bulletin of the American Meteorological Society, 78, 2539-2558.

Yoder, B. J., \& Waring, R. H. (1994). The Normalized Difference Vegetation Index of small Douglas-fir canopies with varying chlorophyll concentrations. Remote Sensing of Environment, 49, 81-91. 